Sports Training

\title{
Measuring the legacy of mega-events: sportive usage index of the Brazil 2014 FIFA World Cup ${ }^{\mathrm{TM}}$
}

\author{
Rômulo Meira Reis ${ }^{1,2}$ (D), Lamartine Pereira DaCosta ${ }^{3}$ (D), Silvio de Cassio Costa Telles ${ }^{3,4}$ (D) \\ ${ }^{1}$ Departamento de Cursos de Graduação, Faculdades Integradas Hélio Alonso Rio de Janeiro, \\ RJ, Brasil; ${ }^{2}$ Confederação Brasileira de Futebol, Rio de Janeiro, RJ, Brasil; ${ }^{3}$ Programa de Pós- \\ Graduação em Ciências do Exercício e do Esporte, Universidade do Estado do Rio de Janeiro, \\ Rio de Janeiro, RJ. Brasil; ${ }^{4}$ Departamento de Corridas, Escola de Educação Física e Desportos, \\ Universidade Federal do Rio de Janeiro, Rio de Janeiro, RJ, Brasil.
}

Associate Editor: Luca Paolo Ardigò, Università di Verona, Verona, Italia.

\begin{abstract}
Aims: This study's general objective is to analyze the sportive usage of the 12 Brazil 2014 FIFA World $\mathrm{Cup}^{\mathrm{TM}}$ arenas. The specific objectives are: (i) To measure the 12 arenas' sportive legacy usage; (ii) To examine and analyze the causes and effects of the results that were found; and (iii) To develop a sportive usage index. Methods: To achieve these objectives, the documental research method was employed. Once in possession of the qualitative and quantitative data, parameters were established for the analysis, which was limited by the seasons from 2014 to 2019 . We then constructed tables and applied statistical treatment. Results: 2014 Season: 215 matches; 2015 Season: 287 matches; 2016 Season: 248 matches; 2017 Season: 260 matches; 2018 Season: 296 matches; and 2019 Season: 325 matches. These results revealed extremes, with some arenas receiving little use and others being highly used. The sportive usage index was about $\cong 23$ matches/year and 2 matches/month. Conclusions: These results are not random and occurred due to matters pertaining to Brazilian soccer peculiarities, with an emphasis on successive increases in the number of competitions; a large number of matches per year; arenas constructed in locations with low popularity teams that receive little use; and political and management issues that interrupted an arena's use (Maracanã in 2016) We recommend that new studies be conducted focusing on the management of these arenas, their state of maintenance and/ or conservation, costs, budgets and the use of public resources in their construction.
\end{abstract}

Keywords: usage index, arenas, legacies, sports mega events, Brazilian soccer.

\section{Introduction}

Sports Mega Events' (SMEs) legacies have been a constant theme in studies and research in various fields of science, generating multifaceted professional and academic perspectives, analyses, and interpretations ${ }^{1-3}$. In this context, there is the understanding that legacies are contextualized by the inheritance left to the host-country in the long term, which may stem from previous impacts such as, for instance, arenas and transportation infrastructure work made possible by the event's economic impacts ${ }^{4}$.

Legacies can be classified as tangible or intangible, planned or not planned, and even be grouped into the following categories: a) Legacy from the event itself sportive constructions, generated jobs and infrastructure improvements; b) Legacy from the event candidacy planning and learning from the process; c) Legacy from the image of the host-country or city - a projection of the image and future economic opportunities, self-confidence and nationalism; d) Legacy from governance - planning, cooperation and participation of various agencies involved in the event management; and e) Legacy from knowledge - production of information, data, and knowledge $^{1,3,5-8}$.

Otherwise, Müller ${ }^{9}$ explains that SMEs generate a type of syndrome, which leads to the excessive promise of future benefits and an underestimation of costs, leading to planning errors. Regarding legacies and their delivery, this can be seen in studies that document facts, present viewpoints, and indicate the existence of positive or negative results, showing criticism and challenges regarding the advantages or disadvantages in hosting SMEs ${ }^{10-19}$.

Thus, to clarify and prove whether the legacies are positive or negative may contribute to a) Influencing and encouraging the interest of cities or nations for SMEs; b) Reducing planning flaws in future SMEs, contributing to the improvement of their legacy; c) Serving as resources, tools and/or indicators for the international entities who own and retain the SMEs to establish a solid dialogue with the cities or nations during the candidacy process ${ }^{2,4,6}$. 
However, to measure and analyze SME legacies is a complex matter which requires the consolidation of variables such as time period, space, planning, type(s) of legacy, viewpoint(s), event finances, local culture, population, and many others which help to define analysis objectives $^{7,8}$. With this challenge in mind, many different forms of measurement or indicator proposals have been developed to establish processes, identify costs and benefits, evaluate or project results of SME legacies ${ }^{2,4,5,7,17,20}$.

Thus, specifically regarding sportive premises and arenas, $\mathrm{Li}$ and $\mathrm{McCabe}^{4}$ propose that they be considered as an analysis item and as indicators in the economic and post-usage perspectives. Ribeiro ${ }^{21}$ defends the legacy of sportive premises, pondering sportive, economic, social, and environmental aspects as indicators. Thus, the $12 \mathrm{Bra}-$ zil 2014 FIFA World $\mathrm{Cup}^{\mathrm{TM}}$ arenas, which are a tangible part of this SME's legacy, represent a vast field for postevent analyses and measurements.

However, the organizers shut down their operations immediately after the event was held ${ }^{22}$. FIFA completely closed its office in Brazil in May 2016; the Local Organizing Committee (Comitê Organizador Local) closed in December 2014 after paying the suppliers, contracts, and personnel; and the Federal Government, which had all of its committees approved by decree, extinguished them in $2018^{22,23}$. With this, there is an absence of delivery and/or public presentation of a post-event legacy plan to the population, especially regarding the 12 arenas, thus not permitting any sort of evaluation of legacy projections and the post-Cup reality.

On the other hand, Reis, Telles, and DaCosta ${ }^{24}$ stated before the delivery of the arenas that one of the main forms of post-usage would be in national soccer competitions; that is, they would be used for sports. Consequently, in accordance with this indication, the study's general objective is to analyze the sportive usage of the 12 Brazil 2014 FIFA World Cup ${ }^{\mathrm{TM}}$ arenas. The specific objectives are: (i) To measure the 12 arenas' sportive legacy usage; (ii) To examine and analyze the causes and effects of the obtained results; and (iii) To develop a sportive usage index.

It is important to emphasize that legacies possess multiple facets and numbers pertaining to financial losses or gains are not sufficient to express their complexity ${ }^{1,25}$. Due to this, we opted to exit the investigative line on the financial variables of economic causes and costs to focus on sportive usage. After all, sports are the main reason for the constitution of SMEs ${ }^{5}$.

Subsequently, this article first presents the Brazilian soccer competition scenario and its context with the 12 arenas. Afterwards, it presents the methodology and the parameters or variables that were selected for analysis. Finally, there are the result analyses and discussions after which the article ends with this study's conclusions, limitations, and implications for future studies.

\section{Brazilian competitions and the legacy of the 12 arenas}

Brazilian soccer is equipped with a productive system, which is connected to market demands, economic factors, and the television media, which intensely publicizes this sport ${ }^{26}$. In this system, the soccer competitions are organized by season in the calendar created by the Brazilian Soccer Federation (CBF in Portuguese), which schedules the pre-season, competition beginning and end dates, FIFA dates, and off-season ${ }^{27}$. Differently from Europe, the Brazilian season occurs between January and December and is not divided between the years, as seen with English, German, Spanish or Italian soccer.

A uniquely Brazilian factor is the existence of state (province) championships, held by the Soccer Federations of each State and usually disputed at the beginning of each year, between the end of January and April ${ }^{27}$. These championships are then followed by the national competitions (from May until the first half of December), which are organized and coordinated by $\mathrm{CBF}$ and have been amplified and treated as different products by the organization ${ }^{28,29}$. This dynamic is revealed when we verify that in 2014 there were eight competitions and in 2019, this number had increased to 20. For 2020, 21 competitions are scheduled (Due to the pandemic caused by the novel coronavirus, national competitions managed by CBF remained paralyzed until July 2020 . However, they restarted in August 2020 and while this article was being written, Brazilian soccer continued to follow CBF's modified calendar in the year 2021), divided among professional, base categories, and women's soccer (non-professional) groups s $^{27,30,31}$.

In this scenario, the competition portfolio varies from year to year. Thus, between the years of 2014 and 2019, we identified eight professional competitions: Cups - Brazil Cup (CB - Copa do Brasil), Northeast Cup and Pre-cup (NE - Pré-Copa and Copa do Nordeste - Although CBF classes the Northeast Pre-Cup as a separate competition, in this study we are considering the Northeast PreCup and Cup as a single competition since the first involves only a few qualifying games for the main cup), and Green Cup (VD - Copa Verde); Championships - Brazilian Soccer Championship (Campeonato Brasileiro de Futebol) in A, B, C, and D series, $1^{\text {st }}, 2^{\text {nd }}, 3^{\text {rd }}$, and $4^{\text {th }}$ divisions ( $\mathrm{A}, \mathrm{B}, \mathrm{C}$, and $\mathrm{D})$. Fifteen competitions in base and women's soccer categories: Female - Female Brazil Soccer Cup (CF - Women's soccer competition which occurred from 2014 to 2016), Brazilian women's soccer Championship (BF - Women's soccer competition which occurred from 2014 to 2016 and was replaced by the A1 Brazilian Female Championship), Brazilian Female Championship (Campeonato Brasileiro Feminino) in $\mathrm{A} 1$ and $\mathrm{A} 2-1^{\text {st }}$ and $2^{\text {nd }}$ divisions (A1 and A2), Sub-18 Female Brazilian Soccer Championship (Campeonato Brasileiro de Futebol 
Feminino Sub-18 - BF18) and Sub-16 Brazilian Soccer Championship (Campeonato Brasileiro de Futebol Sub-16 - BF16); Base categories: Sub-23 - Brazilian Aspirant Championship (Campeonato Brasileiro de Aspirantes ASP); Sub-20 - State Cup (Copa de Seleções Estaduais SE20 - Women's soccer competition which occurred from 2014 to 2016 and was replaced by the A1 Brazilian Female Championship), Brazil SuperCup (SuperCopa do Brasil - SC20), Brazil Cup (Copa do Brasil - C20), Brazilian Championship (Campeonato Brasileiro - B20) and Northeast Cup (Copa do Nordeste - N20); Sub-17 - Brazil SuperCup (SuperCopa do Brasil - SC17), Copa do Brasil (Brazil Cup - C17) and Brazilian Championship (Campeonato Brasileiro - B17) ${ }^{27,30-37}$.

On the other hand, the growing number of competitions proportionally increases the number of games ${ }^{28,29}$. Games in 2018 surpassed 2000 and in the 2020 season, the prediction should surpass 2500 games/year, including the use of the 12 arenas from the Brazil 2014 FIFA World Cup $^{\mathrm{TM}}$ legacy ${ }^{27,35,36}$.

In Table 1, we show the legacy arenas with their respective locations in Brazil's macro-regions, States, and cities.

The arenas possess particularities such as they exist in a larger number than the average from other editions of the world cup; they are distributed throughout the country's five macro-regions (North, Northeast, Mid-west, Southeast, and South); they are located in the State capitals (except for the State of Pernambuco, which has Recife as its capital); they are located in the country's main economic capitals (São Paulo, Rio de Janeiro, Minas Gerais, and the Rio Grande do Sul); and they were constructed in a continental country where logistics are irregular and seen as a complication, which influences the staging of competitions $^{22}$.

In this context, in the relationship between arenas and national competitions, we discovered that the compe- titions are present in greater quantity within the season (thus generating more matches) and include all arenas, thus allowing us to examine them individually and as a whole.

\section{Method}

In order to achieve the proposed objectives, we used the documental research method, aiming to obtain qualitative and quantitative data ${ }^{38}$. Documental research sources are supported by specific materials or documents that diverge from traditional bibliography and have not received any analytical treatment ${ }^{38}$, such as specialized articles, documents, reports, letters, slides, photographs, memoranda, and others ${ }^{38}$. Thus, the sources were separated, quantified, classified, and categorized as $1 . \mathrm{CBF}$ Management Reports; Official CBF Documents; 2. Specific Competition Rules; 3. Official Calendars; 4. Official Schedules; and 5. Official CBF Tables.

The materials were read and the established analysis parameters adopted the following inclusion and exclusion criteria: a) Time - limited by the $2014-2019$ seasons, as although the World Cup occurred in June of 2014, some stadiums were delivered beforehand and hosted matches in national competitions, as occurred with Maracanã, Beira-Rio, Fonte Nova and Mané Garrincha; b) Space Arenas distributed throughout the continental country's five macro-regions; c) Team competitions - the Brazilian national team's competitions or matches, as well as those of its other categories, were not included; d) National competitions - due to their amount, their occurrence during the annual season and since they enable the inclusion of all legacy arenas; e) Brazilian soccer - international competitions disputed by the teams were not included; and f) Official matches - only official matches held in the arenas were accepted. Friendly and commemorative matches were excluded, as well as other events.

Table 1 - Brazil 2014 FIFA World Cup ${ }^{\mathrm{TM}}$ Arenas.

\begin{tabular}{lccc}
\hline Macro-Region & State & City & Arena \\
\hline North & Amazonas & Manaus & Arena da Amazônia \\
Southeast & São Paulo & São Paulo & Arena Corinthians \\
South & Paraná & Curitiba & Arena da Baixada \\
Northeast & Rio Grande do Norte & Natal & Arena das Dunas \\
Northeast & Bahia & Salvador & Arena Fonte Nova \\
Mid-west & Mato Grosso & Cuiabá & Arena Pantanal \\
Northeast & Pernambuco & São Lourenço da Mata & Arena Pernambuco \\
South & Rio Grande do Sul & Porto Alegre & Beira-Rio \\
Northeast & Ceará & Fortaleza & Castelão \\
Mid-west & Distrito Federal & Brasília & Mané Garrincha \\
Southeast & Rio de Janeiro & Rio de Janeiro & Maracanã \\
Southeast & Minas Gerais & Belo Horizonte & Mineirão \\
\hline
\end{tabular}


After the data collection, we examined and assessed the national competitions by season and their respective matches in accordance with the defined parameters. Afterwards, we mapped and quantified the competitions that included the arenas as hosts.

Finally, we treated the data by constructing tables and applying statistics. With the results in hand, we executed analyses, interpretations, and inferences within the following analysis categories, organized by season: 2014 Season; 2015 Season; 2016 Season; 2017 Season; 2018 Season; 2019 Season; and Usage Index.

\section{Results and discussion}

\section{Season}

The 2014 season consisted of eight competitions, with the Brazilian Soccer Championship in A, B, C, and D series and the Brazil Cup beginning before the World Cup; and the Brazilian women's soccer Cup (BF) and Sub-20 Brazil Cup (C20) occurring in September ${ }^{30,39}$. Thus, in Table 2, it is possible to observe that the arenas received 215 matches. The A Series Brazilian Championship was the competition with the highest number of games, answering for $54.2 \%$ of the total, since the clubs belonging to the first division of Brazilian soccer, based in the host cities, regularly use the arenas.

Horizontally, it is possible to note that Arena da Amazônia (three), Mané Garrincha (five), and Arena Pantanal (13) received the lowest number of matches, confirming the prediction made by Reis, Telles, and DaCosta $^{24}$ about the possibility of said arenas having low usage due to the low national popularity of the local soccer teams.

Maracanã (42), Arena Pernambuco (25), and Arena das Dunas (24) stand out with the largest number of matches. This can be explained due to Maracanã receiving

Table 2 - Arena usage in the 2014 season.

\begin{tabular}{lccccccccc}
\hline Arena & A & B & C & D & CB & CF & C20 & C17 & Total \\
\hline Arena da Amazônia & 2 & 1 & - & - & - & - & - & - & 3 \\
Arena Corinthians & 13 & - & - & - & 3 & - & - & - & 16 \\
Arena da Baixada & 14 & - & - & - & 1 & - & - & - & 15 \\
Arena das Dunas & - & 19 & - & - & 5 & - & - & - & 24 \\
Arena Fonte Nova & 14 & - & - & - & 1 & - & - & - & 15 \\
Arena Pantanal & 2 & 2 & 6 & 2 & 1 & - & - & - & 13 \\
Arena Pernambuco & 5 & 20 & - & - & - & - & - & - & 25 \\
Beira-Rio & 14 & - & - & - & 1 & - & 2 & - & 17 \\
Castelão & - & 11 & 6 & - & 2 & - & - & - & 19 \\
Mané Garrincha & 3 & 2 & - & - & - & - & - & - & 5 \\
Maracanã & 34 & 1 & - & - & 7 & - & - & - & 42 \\
Mineirão & 15 & - & - & - & 6 & - & - & - & 21 \\
Total & 116 & 56 & 12 & 2 & 27 & 0 & 2 & 0 & 215 \\
\hline
\end{tabular}

matches from three Rio teams simultaneously (Fluminense, Botafogo, and Flamengo). Arena das Dunas (home of América de Natal) and Arena Pernambuco (home of Náutico) also had teams from their respective states participating in the competitions. Thus, it is understood that sportive usage is proportional to the presence of a participating team, especially in long-term competitions, as is the case in the A and B Series; that is, competitions with elite teams ${ }^{24}$.

\section{Season}

In the 2015 season, there were 14 competitions. This was the first season in which all the arenas were available for use from the beginning of the year onwards ${ }^{32,39}$. With this, it is possible to detect an increase in the total of matches, which numbered 287 (an increase of 73 matches); that is, a $33.5 \%$ increase in volume.

Upon analyzing Table 3, there is evidence of low participation in the arenas in the base and women's soccer competitions. In fact, three competitions: Brazil Cup Sub17 (C17), Northeast Cup Sub-20 (N20), and State Cup (SE20) showed zero usage; that is, none of the matches in these championships happened in the arenas. The reason for this, for N20 and SE20, has to do with the competition formats, since the competitions were held in the State of Alagoas and in the interior of the State of São Paulo, places that do not have legacy arenas ${ }^{32}$. Thus, this format ended up automatically excluding them. As for $\mathrm{C} 17$, the participating clubs did not use the arenas for base category soccer matches because they preferred to leave them available for professional games.

As for the matches that were held in each stadium, Maracanã (43 matches) is the leader, followed by Castelão (33 matches), Arena Fonte Nova (32 matches), and Arena Pernambuco (32 matches). On the other hand, with less than 10 annual games, we have Arena da Amazônia (five matches) and Mané Garrincha (eight matches).

Among the exponent competitions with the greatest number of matches, the A Series remained in evidence (127 matches), followed by the B Series (64 matches). This situation tends to repeat itself because these competitions follow the points system (teams confront each other in alternate matches as the home team and visitor), in which each competition has 38 rounds. As such, there is a total of 760 games ( 380 per competition), with the 12 arenas as possible stages ${ }^{32}$. Examples of this conjuncture are detected with Corinthians (Arena Corinthians), Internacional (Beira-Rio), Athletico Paranaense (Arena da Baixada), Ceará (Castelão) and Bahia (Arena Fonte Nova).

\section{Season}

The 2016 season had 13 competitions, in a spectrum like 2015, excluding the State Cup ${ }^{33,39}$. Thus, 2016 showed a reduction of $13.6 \%$ in the global index in com- 
Table 3 - Arena Usage in the 2015 season.

\begin{tabular}{|c|c|c|c|c|c|c|c|c|c|c|c|c|c|c|c|}
\hline Arena & NE & VD & $\mathbf{A}$ & $\mathbf{B}$ & $\mathbf{C}$ & D & CB & $\mathbf{C F}$ & $\mathbf{B F}$ & $\mathrm{C20}$ & B20 & $\mathrm{C17}$ & $\mathbf{N 2 0}$ & SE20 & Total \\
\hline Arena da Amazônia & - & 1 & - & - & - & 4 & - & - & - & - & - & - & - & - & 5 \\
\hline Arena Corinthians & - & - & 18 & - & - & - & 1 & - & - & - & - & - & - & - & 19 \\
\hline Arena da Baixada & - & - & 18 & - & - & - & 2 & - & - & 1 & - & - & - & - & 21 \\
\hline Arena das Dunas & 4 & - & 1 & 4 & 9 & - & 2 & 1 & - & - & - & - & - & - & 21 \\
\hline Arena Fonte Nova & 6 & - & - & 24 & - & - & 2 & - & - & - & - & - & - & - & 32 \\
\hline Arena Pantanal & - & 4 & 3 & 1 & 9 & 4 & 3 & 1 & 2 & - & - & - & - & - & 27 \\
\hline Arena Pernambuco & 3 & - & 7 & 20 & - & - & 2 & - & - & - & - & - & - & - & 32 \\
\hline Beira-Rio & - & - & 19 & - & 1 & - & 2 & - & - & - & - & - & - & - & 22 \\
\hline Castelão & 7 & - & - & 13 & 10 & - & 3 & - & - & - & - & - & - & - & 33 \\
\hline Mané Garrincha & - & 1 & 4 & 2 & - & 1 & - & - & - & - & - & - & - & - & 8 \\
\hline Maracanã & - & - & 34 & - & - & - & 8 & - & - & - & 1 & - & - & - & 43 \\
\hline Mineirão & - & - & 23 & - & - & - & 1 & - & - & - & - & - & - & - & 24 \\
\hline Total & 20 & 6 & 127 & 64 & 29 & 9 & 26 & 2 & 2 & 1 & 1 & 0 & 0 & 0 & 287 \\
\hline
\end{tabular}

parison to 2015, as the Maracanã stadium was ceded with exclusivity to the Rio 2016 Committee for the Rio 2016 Olympic Games and did not hold soccer matches. After the Olympic Games, upon the arena's return to active status, Maracanã S/A (the arena's manager, belonging to the Odebrecht construction company group) and the Rio 2016 Committee had a disagreement over the state in which the arena was returned.

Simultaneously, Maracanã S/A was involved in a legal battle to return the arena to the Rio de Janeiro State Government due to bidding conditions that were not fulfilled by the government ${ }^{40}$. This legal and political imbroglio persisted in 2016, forcing the Flamengo and Fluminense soccer teams to play elsewhere. Due to this, the arena's usage went down, affecting its general index.

As for the number of matches received (Table 4), Castelão (39) and Arena Fonte Nova (29) remained in the top positions, followed by Arena da Baixada (28). On a negative note, Arena da Amazônia held nine matches, as well as Mané Garrincha, and Maracanã only held seven. Once again, the N20 (still held in the State of Alagoas) had zero matches. However, we bring up the following question: Was it not possible to hold the competition finals in a nearby arena? After all, the Northeast Region has four arenas as references (Arena Pernambuco, Arena das Dunas, Arena Fonte Nova, and Castelão).

\section{Season}

There were 16 competitions in 2017 , three more than in 2016. Two of them were new: The Brazilian Aspirant Championship (Sub-23 - ASP) and the Sub-20 SuperCup (SC20) and the Sub-20 State Cup returned (SE20) ${ }^{34,39,41}$.

Upon examining Table 5 vertically, the A Series (103) and B Series (62) stand out, followed by the Brazil

Table 4 - Arena usage in the 2016 season.

\begin{tabular}{|c|c|c|c|c|c|c|c|c|c|c|c|c|c|c|}
\hline Arena & $\mathbf{N E}$ & VD & $\mathbf{A}$ & B & $\mathbf{C}$ & D & $\mathbf{C B}$ & $\mathbf{C F}$ & $\mathbf{B F}$ & $\mathrm{C} 20$ & B20 & C17 & $\mathbf{N 2 0}$ & Total \\
\hline Arena da Amazônia & - & 2 & - & 1 & - & 2 & 1 & - & 3 & - & - & - & - & 9 \\
\hline Arena Corinthians & - & - & 18 & - & - & - & 2 & - & - & - & 1 & - & - & 21 \\
\hline Arena da Baixada & - & - & 18 & - & - & - & 4 & - & - & 2 & 2 & 2 & - & 28 \\
\hline Arena das Dunas & 3 & - & 1 & - & 8 & - & 1 & - & - & - & - & - & - & 13 \\
\hline Arena Fonte Nova & 5 & - & 3 & 18 & - & - & 3 & - & - & - & - & - & - & 29 \\
\hline Arena Pantanal & - & 2 & 2 & - & 9 & - & 4 & - & - & - & - & - & - & 17 \\
\hline Arena Pernambuco & - & - & 3 & 18 & - & - & 1 & - & - & - & - & - & - & 22 \\
\hline Beira-Rio & - & - & 19 & - & - & - & 4 & - & - & - & - & - & - & 23 \\
\hline Castelão & 5 & - & - & 19 & 10 & - & 5 & - & - & - & - & - & - & 39 \\
\hline Mané Garrincha & - & 1 & 7 & 1 & - & - & - & - & - & - & - & - & - & 9 \\
\hline Maracanã & - & - & 6 & 1 & - & - & - & - & - & - & - & - & - & 7 \\
\hline Mineirão & - & - & 22 & - & - & - & 9 & - & - & - & - & - & - & 31 \\
\hline Total & 13 & 5 & 99 & 58 & 27 & 2 & 34 & 0 & 3 & 2 & 3 & 2 & 0 & 248 \\
\hline
\end{tabular}


Table 5 - Arena usage in the 2017 season.

\begin{tabular}{|c|c|c|c|c|c|c|c|c|c|c|c|c|c|c|c|c|c|}
\hline Arena & $\mathbf{N E}$ & VD & $\mathbf{A}$ & $\mathbf{B}$ & $\mathbf{C}$ & D & CB & A1 & $\mathbf{A 2}$ & $\mathrm{C20}$ & B20 & $\mathrm{C} 17$ & $\mathbf{N 2 0}$ & SE20 & ASP & SC20 & Total \\
\hline Arena da Amazônia & - & 1 & - & - & - & 3 & 1 & 6 & - & - & - & - & - & - & - & - & 11 \\
\hline Arena Corinthians & - & - & 19 & - & - & - & 2 & - & - & - & - & 2 & - & - & - & - & 23 \\
\hline Arena da Baixada & - & - & 20 & 1 & - & - & 2 & - & - & 1 & 6 & - & - & - & 2 & - & 32 \\
\hline Arena das Dunas & 3 & - & - & 3 & - & 6 & 1 & - & - & - & - & - & - & - & - & - & 13 \\
\hline Arena Fonte Nova & 5 & - & 18 & - & - & - & - & - & - & - & - & - & - & - & - & - & 23 \\
\hline Arena Pantanal & - & 2 & - & 4 & 9 & - & 1 & - & 3 & - & - & - & - & - & - & - & 19 \\
\hline Arena Pernambuco & 3 & - & 2 & 19 & - & - & - & - & 3 & - & - & - & - & 2 & - & - & 29 \\
\hline Beira-Rio & - & - & - & 19 & - & - & 4 & - & - & - & 1 & - & - & - & 3 & - & 27 \\
\hline Castelão & 4 & - & - & 16 & 7 & - & - & - & - & - & - & - & - & - & - & - & 27 \\
\hline Mané Garrincha & - & - & - & - & - & - & - & - & - & - & - & - & - & - & - & - & 0 \\
\hline Maracanã & - & - & 24 & - & - & - & 5 & - & - & - & - & - & - & - & - & - & 29 \\
\hline Mineirão & - & - & 20 & - & - & - & 7 & - & - & - & - & - & - & - & - & - & 27 \\
\hline Total & 15 & 3 & 103 & 62 & 16 & 9 & 23 & 6 & 6 & 1 & 7 & 2 & 0 & 2 & 5 & 0 & 260 \\
\hline
\end{tabular}

Cup (23). Compared to the use of these arenas in 2016, only the Brazil Cup obtained a lower usage index $(-47.83 \%)$.

The global number of games increased by $4.8 \%$ when compared with 2016. The best performance is attributed to Arena da Baixada (32), Arena Pernambuco (29), Maracanã (29), Beira-Rio (27), Castelão (27) and Mineirão (27). Arenas without fixed teams, such as Mané Garrincha, which was the first to show an index of zero matches in a season, Arena da Amazônia (11) and Arena Pantanal (19) underwent reductions in their numbers of matches. This said, we believe that this is due to a change in the specific regulations of the A and B Series, which established that arenas outside the team's state should not be used, as per articles 21 and 19, respectively: "Home advantage will necessarily occur within the jurisdiction of the Federation to which the home team belongs. Said team shall not have the home advantage outside of its State"42 $\left(\right.$ p.13) ${ }^{43}$ (p.11).

Thus, the use of "external" arenas remained nonviable, especially for teams from Rio de Janeiro and São Paulo, such as Flamengo, Vasco, Corinthians, and Palmeiras, which used to play in the Mané Garrincha arena in Brasília, for instance. However, CBF reviewed its position for 2018 and removed the aforementioned articles that "forbid" matches outside of the clubs' States ${ }^{44,45}$.

\section{Season}

In the 2018 season, we identified 20 competitions $^{35,36,39}$. Nonetheless, as explained at the beginning of this article, the Northeast Pre-Cup and Cup (NE) are interpreted as a single competition because the Pre-Cup consists of a small number of qualifying matches for the main Cup.

In Table 6 , there was an increase of $13.8 \%$ in the global number of matches. It is also possible to notice that the base category and women's soccer competitions consist of 42 matches, $14.2 \%$ of the total. As it is, five competitions (BF18, BF16, B17, SC20, and SC17) never even held a match in one of the 12 legacy arenas, obtaining a zero index. Thus, the competitions in the base and women's soccer categories had little significance in terms of sportive usage in 2018.

The number of matches in the A Series grew significantly $(47.5 \%)$, representing 47 matches. The three arenas with the highest usage indexes are Castelão (45), Maracanã (41), and Beira-Rio (32). The numbers for Castelão and Maracanã can be explained due to both arenas having two teams with frequent matches, with Ceará and Fortaleza in the Castelão and Flamengo and Fluminense in Maracanã, in Rio de Janeiro, a situation that can, on the other hand, lead to wear and tear and little recovery time for the field, affecting the quality of the entertainment.

As for Beira-Rio, the home team (Internacional) stood out in all the competitions it participated in, especially in the A2 Brazilian Female Championship (A2), where the club gained access to participate in the A1 Brazilian Female Championship in 2019. With this, the good results on the field led to the team having more matches in the competition, improving the team's ranking in the divisions (access), and contributing to the arena's sportive usage.

On the other hand, the arenas with the lowest indexes were: Arena das Dunas (seven) and Mané Garrincha (eight), once again due to the deficiency these arenas possess, with home teams that have low expressiveness in Brazilian soccer, participating in the $3^{\text {rd }}$ and $4^{\text {th }}$ divisions.

\section{Season}

In 2019, we detected 19 competitions that followed the same format as $2018^{31,37,39}$. In this configuration, the 
Table 6 - Arena usage in the 2018 season

\begin{tabular}{|c|c|c|c|c|c|c|c|c|c|c|c|c|c|c|c|c|c|c|c|c|}
\hline Arena & NE & VD & $\mathbf{A}$ & B & $\mathbf{C}$ & D & CB & A1 & $\mathbf{A 2}$ & BF18 & BF16 & $\mathrm{C20}$ & B20 & B17 & $\mathrm{C} 17$ & ASP & $\mathbf{N 2 0}$ & SC20 & SC17 & Total \\
\hline Arena da Amazônia & - & 3 & - & - & - & 3 & 2 & 7 & 5 & - & - & - & - & - & - & - & - & - & - & 20 \\
\hline Arena Corinthians & - & - & 19 & - & - & - & 4 & 1 & - & - & - & 1 & - & - & - & - & - & - & - & 25 \\
\hline Arena da Baixada & - & - & 19 & - & - & - & 4 & - & - & - & - & 1 & 1 & - & 1 & 5 & - & - & - & 31 \\
\hline Arena das Dunas & 1 & - & - & - & - & 3 & - & - & - & - & - & - & - & - & - & - & 3 & - & - & 7 \\
\hline Arena Fonte Nova & 5 & - & 17 & - & - & - & 2 & - & - & - & - & - & - & - & - & - & - & - & - & 24 \\
\hline Arena Pantanal & - & 2 & - & - & 12 & 3 & 3 & - & - & - & - & - & - & - & - & - & - & - & - & 20 \\
\hline Arena Pernambuco & 4 & - & 1 & - & 10 & - & 2 & - & 1 & - & - & - & - & - & - & 2 & - & - & - & 20 \\
\hline Beira-Rio & - & - & 19 & - & - & - & 2 & - & 2 & - & - & 1 & 2 & - & - & 6 & - & - & - & 32 \\
\hline Castelão & 5 & - & 14 & 19 & - & 5 & 2 & - & - & - & - & - & - & - & - & - & - & - & - & 45 \\
\hline Mané Garrincha & - & 1 & 3 & - & - & 3 & 1 & - & - & - & - & - & - & - & - & - & - & - & - & 8 \\
\hline Maracanã & - & - & 36 & - & - & - & 3 & - & - & - & - & - & - & - & 2 & - & - & - & - & 41 \\
\hline Mineirão & - & - & 18 & - & - & - & 4 & - & - & - & - & - & 1 & - & - & - & - & - & - & 23 \\
\hline Total & 15 & 6 & 146 & 19 & 22 & 17 & 29 & 8 & 8 & 0 & 0 & 3 & 4 & 0 & 3 & 13 & 3 & 0 & 0 & 296 \\
\hline
\end{tabular}

consolidated data in Table 7 reveals that the matches reached a total of 325 (29 matches more), with an increase of $9.8 \%$. The main reasons behind this increase are the use of Mineirão by Atlético Mineiro in the A Series and Arena Pantanal by Cuiabá, which played its first season in the B Series, which has more matches than the C Series.

Within the global amount, the base and women's soccer categories remained with little representativity (44), accounting for $13.5 \%$ of the matches. Two competitions did not hold matches in the arenas: the Sub-16 Female Brazilian Championship (BF16) and the Sub-20 Brazil SuperCup (SC20). The three "best" indexes in this group belong to the Sub-20 Brazilian Championship (14) and the A1 and A2 Female Brazilian Championship (both with eight matches).

In the professional competitions, the two highest results other than the A Series stem from the Brazil Cup
- CB - (31) and the B Series of the Brazilian Soccer Championship (25). The worst results came from the Green Cup - VD - (seven) and the C Series (eight). Specifically, regarding the Green Cup, this occurred due to the competition contemplating teams from the North and Mid-west macro-regions of the country, which contain only two legacy arenas (Arena da Amazônia and Arena Pantanal).

The three highest individual usage indexes belong to: Castelão (57), Maracanã (44) and Arena da Baixada (39), due to the performance of Ceará and Fortaleza in Castelão and Flamengo and Fluminense in Maracanã. As for Athlético Paranaense, the team obtained good results in 2019, winning the Brazil Cup and thus playing more games. On the other hand, the lowest usage occurred at Mané Garrincha (five), Arena das Dunas, and Arena da Amazônia (both with 14).

Table 7 - Arena usage in the 2019 season.

\begin{tabular}{|c|c|c|c|c|c|c|c|c|c|c|c|c|c|c|c|c|c|c|c|c|}
\hline Arena & $\mathbf{N E}$ & VD & $\mathbf{A}$ & B & $\mathbf{C}$ & D & $\mathbf{C B}$ & $\mathbf{A 1}$ & A2 & BF18 & BF16 & $\mathrm{C20}$ & B20 & B17 & $\mathrm{C} 17$ & ASP & N20 & SC20 & SC17 & Total \\
\hline Arena da Amazônia & - & 3 & 1 & - & - & 5 & - & 4 & 1 & - & - & - & - & - & - & - & - & - & - & 14 \\
\hline Arena Corinthians & - & - & 19 & - & - & - & 4 & - & - & - & - & - & - & - & - & - & - & - & - & 23 \\
\hline Arena da Baixada & - & - & 19 & - & - & - & 4 & - & - & - & - & - & 8 & 5 & - & 3 & - & - & - & 39 \\
\hline Arena das Dunas & 1 & - & - & - & - & 8 & 2 & - & 2 & - & - & 1 & - & - & - & - & - & - & - & 14 \\
\hline Arena Fonte Nova & 4 & - & 16 & 3 & - & - & 4 & - & - & - & - & - & - & - & - & - & - & - & - & 27 \\
\hline Arena Pantanal & - & 4 & - & 19 & - & - & 2 & - & 3 & - & - & 1 & - & - & - & - & - & - & - & 29 \\
\hline Arena Pernambuco & 2 & - & - & 3 & 2 & 4 & - & 1 & - & 4 & - & - & 6 & - & 1 & - & 1 & - & - & 24 \\
\hline Beira-Rio & - & - & 19 & - & - & - & 4 & 1 & - & - & - & - & - & - & - & 1 & - & - & - & 25 \\
\hline Castelão & 11 & - & 38 & - & 6 & - & 2 & - & - & - & - & - & - & - & - & - & - & - & - & 57 \\
\hline Mané Garrincha & - & - & 5 & - & - & - & - & - & - & - & - & - & - & - & - & - & - & - & - & 5 \\
\hline Maracanã & - & - & 37 & - & - & - & 6 & - & - & - & - & - & - & - & - & - & - & - & 1 & 44 \\
\hline Mineirão & - & - & 21 & - & - & - & 3 & - & - & - & - & - & - & - & - & - & - & - & - & 24 \\
\hline Total & 18 & 7 & 175 & 25 & 8 & 17 & 31 & 6 & 6 & 4 & 0 & 2 & 14 & 5 & 1 & 4 & 1 & 0 & 1 & 325 \\
\hline
\end{tabular}




\section{Usage index}

The results are contained in this category, presented, and analyzed in a consolidated manner in order to form the sportive usage index (Table 8).

The consolidated figures show that the matches held in the arenas reached a total of 1631 within the analyzed period. Individually, the arenas with the most matches were Castelão (220), Maracanã (206), Arena da Baixada (166), and Arena Pernambuco (152), averaging around 186 matches/year for those arenas. On the other hand, the lower levels remained with Mané Garrincha (35), Arena da Amazônia (62), and Arena das Dunas (92), averaging 63 matches/year for the group.

Taking the 2014 season as the starting point (zero), it is possible to examine the evolution of the number of matches throughout the years: $2015(+33.5 \%), 2016$ $(+15.3 \%), 2017(+20.9 \%), 2018(+37.7 \%)$ and 2019 $(+51.2 \%)$. Thus, it is possible to perceive number increases in all the years, a direct reflex of the increase in national competitions promoted by CBF.

With the consolidated data, we propose examining the sportive usage index through the Matches/year and Matches/month coefficients. In this line of action, we use the following calculations: (Matches/year $=$ Average/Arenas) and (Matches/month $=$ Matches/year/Months of competition). We considered months of competition as 11 months since we discounted the period destined to vacation time and preseason. Thus, the sportive usage index results in $\cong 23$ Matches/year and 2 Matches/month.

In order to obtain a notion of the reality and applicability of this measurement, we conducted a brief comparison with European soccer. The elite teams of Europe generally dispute a national league in their countries with 20 teams (La Liga, Premier League or Lega Serie A) and one Cup (Copa del Rey, The FA Cup or Coppa Italia) with varying numbers of participants due to the system in each competition $^{46-51}$. In this context, a team can participate in up to 19 home matches for the national league ( $1^{\text {st }}$ division) and on average around five home matches for the Cup (depending on the team's performance), reaching a total of 24 home matches (The UEFA Champions League and Europa League are continental competitions, similar to the CONMEBOL Libertadores and Sudamericana). Thus, their respective matches are not included. Thus, the number of $\cong 23$ Matches/year is close to the European reality and can be considered a good usage index.

\section{Conclusions}

Throughout the article, we measured the sportive usage of the Brazil 2014 FIFA World Cup's ${ }^{\mathrm{TM}} 12$ legacy arenas within the selected analysis parameters, quantitatively revealing how the 12 arenas were used in national Brazilian soccer competition from 2014 to 2019. The data in the results section shows that the results obtained within the chosen seasons did not occur randomly, but rather due to the peculiarities of Brazilian soccer as a sport, establishing a cause-and-effect relationship. With this in mind, we point out the following: a) Successive increases in the number of competitions; b) A large number of matches per year; c) The presence or absence of elite soccer teams using the arenas; d) Seldom used arenas constructed in locations that are home to teams with low expressiveness (Mané Garrincha, Arena da Amazônia and Arena das Dunas); e) The teams' performance and competitiveness influence usage, as when the team reaches the A or B Series, it enters a long-term competition with 19 matches predicted for its arena; f) Political and management issues may interrupt the use of an arena, as was the case of Maracanã in 2016; and g) Arenas with a large number of matches.

Table 8 - Consolidated arena usage for the 2014-2019 seasons.

\begin{tabular}{|c|c|c|c|c|c|c|c|c|}
\hline Arena & 2014 & 2015 & 2016 & 2017 & 2018 & 2019 & Average & Total \\
\hline Arena da Amazônia & 3 & 5 & 9 & 11 & 20 & 14 & 10 & 62 \\
\hline Arena Corinthians & 16 & 19 & 21 & 23 & 25 & 23 & 21 & 127 \\
\hline Arena da Baixada & 15 & 21 & 28 & 32 & 31 & 39 & 28 & 166 \\
\hline Arena das Dunas & 24 & 21 & 13 & 13 & 7 & 14 & 15 & 92 \\
\hline Arena Fonte Nova & 15 & 32 & 29 & 23 & 24 & 27 & 25 & 150 \\
\hline Arena Pantanal & 13 & 27 & 17 & 19 & 20 & 29 & 21 & 125 \\
\hline Arena Pernambuco & 25 & 32 & 22 & 29 & 20 & 24 & 25 & 152 \\
\hline Beira-Rio & 17 & 22 & 23 & 27 & 32 & 25 & 24 & 146 \\
\hline Castelão & 19 & 33 & 39 & 27 & 45 & 57 & 37 & 220 \\
\hline Mané Garrincha & 5 & 8 & 9 & 0 & 8 & 5 & 6 & 35 \\
\hline Maracanã & 42 & 43 & 7 & 29 & 41 & 44 & 34 & 206 \\
\hline Mineirão & 21 & 24 & 31 & 27 & 23 & 24 & 25 & 150 \\
\hline Total & 215 & 287 & 248 & 260 & 296 & 325 & 272 & 1631 \\
\hline
\end{tabular}


The sportive usage index of $\cong 23$ Matches/year and 2 Matches/month provides a notion of the sample's homogeneity. However, the reality is different for Mané Garrincha, Arena da Amazônia, and Arena das Dunas, whose results have not surpassed the mark of 100 matches in six years. Thus, they confirm the premise established by Ribeiro $^{21}$ and Reis, Telles, and DaCosta ${ }^{24}$ about the presence of "white elephants" among the 12 legacy arenas. On the other hand, there appears to be a situation of overuse at Castelão and Maracanã, arenas that surpass the mark of 200 Matches/year. Thus, there are extremes, with some arenas seeing lots of use and others seeing very little. It is important to highlight that in the case of the FIFA Brazil 2014 World Cup ${ }^{\mathrm{TM}}$, we sought access to the bid (candidacy dossier) Brazil sent to FIFA but did not gain access to the document and consequently were unable to compare or even verify whether this variable was included.

Moreover, we believe the level of $\cong 23$ Matches/year is relevant and may be considered directly for planning future editions of the FIFA World $\mathrm{Cup}^{\mathrm{TM}}$, avoiding the low usage of arenas and serving as a parameter in the search for a homogeneous use among the sports facilities geared towards soccer. We also believe that this index's proposition may be adapted for other types of sports facilities, as long as the sport's characteristics are respected (rounds, events, matches, circuits, championships, meets, opens, tournaments, competition schedules, etc.), as well as the host-nation or city's culture, in order to better fulfill the concept of SME legacy.

\section{Limitations and future studies}

It is necessary to remember that the content displayed in this article is far from exhausting the subject. However, the sportive usage indicator is another element that can improve the measurement of SMEs legacies, as well as aspects connected to finances, economy, management, tourism, the environment, sustainability, local culture, society, and knowledge.

Specifically, regarding the legacy of the 12 Brazil 2014 FIFA World Cup ${ }^{\mathrm{TM}}$ arenas, we recommend that new studies be conducted regarding the management of this equipment, their state of maintenance and/or conservation, costs, budgets, and the employment of public resources in their construction. Other subjects to investigate are the cost-benefit considering fan attendance and arena occupation percentages, the revenue that is generated for the club or for the stadium administrator, the jobs that are generated (directly or indirectly), and benefits and auxiliary activities for the city's population that are associated with the arena's existence.

\section{Conflicts of interest}

None.

\section{References}

1. Chappelet JL. Mega Sporting Event Legacies: A Multifaceted Concept. Papeles De Europa. 2012; 25:76-86. DOI: 10.5209/rev_PADE.2012.n25.41096.

2. Preuss H. Event legacy framework and measurement. Int J Sport Policy Politics. 2019;11(1):103-18. https://doi.org/ 10.1080/19406940.2018.1490336

3. Thomson A, Schlenker K, Schulenkorf N. Conceptualizing Sport Event Legacy. Event Managemen. 2013;17(2):111-22. http://dx.doi.org/10.3727/152599513X13668224082260

4. Li S, McCabe S. Measuring the Socio-Economic Legacies of Mega-events: Concepts, Propositions, and Indicators. Int. J. Tourism Res. 2013;15:388-402. https://doi.org/10.1002/ jtr. 1885

5. DaCosta LP, Correa D, Rizzuti E, Villano B, Miragaya A. (Eds). Legados de megaeventos esportivos. [Sportive mega events legacies]. Brasília, Ministério do Esporte, 2008.

6. Gratton C, Preuss H. Maximizing Olympic Impacts by Building Up Legacies. Int J History Sport. 2008;25 (14):1922-38. https://doi.org/10.1080/09523360802439023

7. Preuss H. The conceptualisation and measurement of mega sport event legacies. J Sport \& Tourism. 2010;12(3-4):20727. DOI: $10.1080 / 14775080701736957$

8. Preuss H. Estruturando os conceitos de legado dos Jogos Olímpicos. [Structuring the concepts of legacy from the Olympic Games]. In: Deslandes, A, DaCosta L, Miragaya A. (Eds.). Futuro dos megaeventos esportivos - inovações pós-Copa 2014 e Jogos Olímpicos e Paralímpicos 2016. (pp. 75-91) Rio de Janeiro. Editora: Engenho, Arte e Cultura, 2015.

9. Müller M. The Mega-Event Syndrome: Why So Much Goes Wrong in Mega-Event Planning and What to Do About It. J Am Planning Assoc. 2015;81:1-12. https://doi.org/10.1080/ 01944363.2015.1038292

10. Bondarik R. Copa do Mundo FIFA de 2014 no Brasil: um drible maroto, desequilibrado e desconcertante nas promessas de legado de um megaevento esportivo. Paraná. [Tese de Doutorado] - Programa de Pós-Graduação em Engenharia de Produção, Universidade Tecnológica Federal do Paraná, 2018.

11. Byers T, Haydey E, Pappous A. A new conceptualization of mega sports event legacy delivery: Wicked problems and critical realist solution. Sport Management Rev. 2020;23 (2):171-82. https://doi.org/10.1016/j.smr.2019.04.001

12. Coakley J, Souza DL. Sport mega-events: can legacies and development be equitable and sustainable? Motriz: J Phys Educ. 2013;19(3):580-9. https://doi.org/10.1590/S198065742013000300008

13. Gaffney CT. The mega event city as neo-liberal laboratory: the case of Rio de Janeiro. Percurso Acadêmico. 2014;4(8). https://doi.org/10.5752/P.2236-0603.2014v0n0p217-237

14. Griffin TR. National identity, social legacy, and Qatar 2022: the cultural ramifications of FIFA's first Arab World Cup. Soccer \& Society. 2019;20(7-8):1000-13. https://doi.org/ 10.1080/14660970.2019.1680499

15. Kassens-Noor E, Wilson M, Müller S, Maharaj B, Huntoon L. Towards a mega-event legacy framework. Leisure Studies. 2015;34(6):665-71. https://doi.org/10.1080/ 02614367.2015 .1035316 
16. Paiva RS. Falácias no planejamento do legado esportivo da Copa do Mundo FIFA nas doze cidades-sede no Brasil. [Tese de Doutorado]. Departamento de Ciências Sociais. Pontifica Católica de São Paulo - PUC-SP, 2018.

17. Preuss H. Impactos econômicos de megaeventos: Copa do Mundo de Futebol e Jogos Olímpicos. In: DaCosta LP, Correa D, Rizzuti E, Villano B, Miragaya A. (Eds.) Legados de megaeventos esportivos. Brasília: Ministério do Esporte, 2008: 79-90.

18. Reis RM, Malina A, DaCosta LP, Telles SCC. Management and legacy of the Brazil 2014 Fifa World Cup during its candidacy bid. Motriz: J Phys Educ. 2019a;25(2): 1-11. https://doi.org/10.1590/s1980-6574201900020016

19. Reis R, Triani F, DaCosta L, Telles SCC. Gestão da Copa do Mundo da FIFA Brasil 2014TM: responsabilidades e atribuições dos organizadores. Revista Valore. 2019b;4(1):841-55. https://doi.org/10.22408/reva412019277841-855

20. Rodrigues MN. Impact/legacy measurement and evaluation in mega event projects with focus on intangible assets. Rio de Janeiro. [Tese de Dourorado]. Programa de Engenharia de Produção, UFRJ/COPPE, 2016.

21. Ribeiro FT. Legado de Megaeventos Esportivos Sustentáveis: a Importância das Instalações Esportivas. In: DaCosta LP, Correa D, Rizzuti E, Villano B, Miragaya A. (Eds). Legados de megaeventos esportivos. Brasília: Ministério do Esporte, 2008:107-16.

22. Reis RM. Copa do Mundo da FIFA Brasil 2014 ${ }^{\mathrm{TM}}$ : gestão e legados da candidatura ao pós-evento. Rio de Janeiro. [Tese de Doutorado] - Instituto de Educação Física e Desportos, Universidade do Estado do Rio de Janeiro, 2017.

23. Brasil. (2018). Decreto $n^{\circ} 9.512$, de 27 de setembro. Diário Oficial da União, 2018. Retirado de: http://www.in.gov.br/ web/dou/-/decreto-n-9-512-de-27-de-setembro-de-201842826624 Accessed on June $1^{\text {st }}, 2020$.

24. Reis RM, Telles SCC, Dacosta LP. Estádios da Copa de 2014: perspectivas de um legado. [2014 World Cup Stadiums: the perspectives of a legacy]. Revista Pensar a Prática. 2013;16(2):566-82. https://doi.org/10.5216/rpp. v16i2.17712

25. Cury MA. Disputa pelo legado em megaeventos esportivos no Brasil. [Legacy dispute in sports mega events in Brazil]. Horizontes Antropológicos. 2013;19(40):65-88. https://doi. org/10.1590/S0104-71832013000200003

26. Reis RM, Remédios JL, Telles SCC, DaCosta LP. The football business in Brazil: Connections between the economy, market and media. Motriz: J Phys Educ. 2014;20(2):120-30. https://doi.org/10.1590/S1980-65742014000200001

27. CBF. CBF publica calendário 2020 com datas FIFA livres. Assessoria de imprensa. 2019b. Available at : https://www. cbf.com.br/futebol-brasileiro/noticias/campeonato-brasi leiro/cbf-publica-calendario-de-2020-com-datas-fifaslivres-e-16-datas-para. Accessed on May 89, 2020.

28. CBF. Relatório de gestão 2016. Rio de Janeiro, 2016c. Available at: https://conteudo.cbf.com.br/cdn/201904/ 20190410114940_544.pdf

29. CBF. Relatório de gestão 2017. [2017 Management Report]. CBF. Rio de Janeiro, 2017e. https://conteudo.cbf.com.br/ cdn/201904/20190410115911_97.pdf
30. CBF. Cronograma das competições do futebol brasileiro/ 2014. Published on Sept 20, 2013. Rio de Janeiro, 2013. Available at: https://conteudo.cbf.com.br/cdn/201312/ 1215115709.pdf

31. CBF. Cronograma das competições do futebol brasileiro/ 2019. Rio de Janeiro, 2018a. Available at: https://conteudo. cbf.com.br/cdn/201810/20181015144219_234.pdf

32. CBF. Cronograma das competições do futebol brasileiro/ 2015. Published on August 06, 2014. Rio de Janeiro, 2014. Available at: https://conteudo.cbf.com.br/cdn/201410/ 20141008231023_0.pdf

33. CBF. Cronograma das competições do futebol brasileiro/ 2016. Published on August 25, 2015. Rio de Janeiro, 2015. Available at: https://conteudo.cbf.com.br/cdn/201508/ 20150825170307_0.pdf

34. CBF. Cronograma das competições do futebol brasileiro/ 2017 categorias de base e futebol feminino. Published on Nov 16, 2016. Rio de Janeiro, 2016b. Available at: https:// conteudo.cbf.com.br/cdn/201701/20170109151606_0.pdf

35. CBF. Cronograma das competições do futebol brasileiro/ 2018. Issued Jul. 06, 2016. Rio de Janeiro, 2017a. Available at: https://conteudo.cbf.com.br/cdn/201709/ 20170929192137_0.pdf

36. CBF. Cronograma das competições do futebol brasileiro/ 2018 categorias de base e futebol feminino. Publishd on Nov16, 2016. Rio de Janeiro, 2017b. Available at: https:// conteudo.cbf.com.br/cdn/201712/20171204175436_0.pdf

37. CBF. Cronograma das competições do futebol brasileiro/ 2018 categorias de base e futebol feminino. Rio de Janeiro, 2019c. Available at: https://conteudo.cbf.com.br/cdn/ 201712/20171204175436_0.pdf

38. Sá-Silva JR, Almeida CD, Guindani JF. Pesquisa documental: pistas teóricas e metodológicas. Revista Brasileira de História \& Ciências Sociais. 2009;1(1):1-15. https://peri odicos.furg.br/rbhcs/article/view/10351/pdf

39. CBF. Futebol brasileiro, competições, tabelas. 2019a. Available at: https://www.cbf.com.br/futebol-brasileiro/competi coes/campeonato-brasileiro-serie-a/2014\#.WyvFwFV KiM8. Accessed: 09 may. 2020.

40. Dolzan M. Justiça do Rio mantém decisão que obriga concessionária a administrar o Maracanã. Apr 4, 2017. Estadão, 2017. Available at: https://revistapegn.globo.com/Negocios/ Noticia/2017/04/pegn-justica-do-Rio-mantem-decisao-queobriga-concessionaria-a-administrar-o-maracana.html

41. CBF. Cronograma das competições do futebol brasileiro/ 2017. Issued o jul 6, 2016. Rio de Janeiro, 2016a. Available at: https://conteudo.cbf.com.br/cdn/201701/ 20170112102000_0.pdf

42. CBF. Regulamento específico da competição campeonato brasileiro da série A 2017. Rio de Janeiro, 2017c. Available at: https://conteudo.cbf.com.br/cdn/201703/ 20170313175547_0.pdf

43. CBF. Regulamento específico da competição campeonato brasileiro da série B 2017. Rio de Janeiro, 2017d. Available at: https://conteudo.cbf.com.br/cdn/201703/ 20170313185738_0.pdf

44. CBF. Regulamento específico da competição campeonato brasileiro da série A 2018. Rio de Janeiro, 2018b. Available 
at:

https://conteudo.cbf.com.br/cdn/201802/

20180215120825_0.pdf

45. CBF. Regulamento específico da competição campeonato brasileiro da série B 2018. Rio de Janeiro, 2018c. Available at: https://conteudo.cbf.com.br/cdn/201802/ 20180215121132_0.pdf

46. LA LIGA. La Liga results. La Liga Santander, 2020. Available at: https://www.laliga.com/en-BR/laliga-santander/ results.

47. LEGA SERIE A. Lega Serie A fictures and results. Lega Serie A, 2020a. Available at: http://www.legaseriea.it/en/ serie-a/fixture-and-results.

48. LEGA SERIE A. Coppa Italia fictures and results. Lega Serie A, 2020b. Available at: http://www.legaseriea.it/en/ coppa-italia/fixture-and-results.

49. PREMIER LEAGUE. Handbook Season 2019/20. The Football Association Premier League Limited. Premier League, 2019. Available at: https://resources.premierleague. com/premierleague/document/2020/05/11/9de08b33-1f944ac7-9868-8bb157807062/2019-20-PL-Handbook-070520. pdf.

50. RFEF. Circular número: 14 Normativa reguladora de la organización y desarrollo de los Campeonatos Nacionales de Liga de Primera, Segunda, Segunda "B" y Tercera División, del Campeonato de España / Copa de SM el Rey, del torneo de Supercopa y de la Copa Real Federación Española Fútbol, correspondientes a la actual temporada 2019/2020. 2019. Available at: https://cdn1.sefutbol.com/sites/default/ files/bases_competiciones_de_ambito_estatal.pdf

51. The FA. Competitions The Emirates FA Cup. The FA, 2020. Available at: http://www.thefa.com/competitions/thefacup/ more/fa-cup-round-dates

\section{Corresponding author}

Rômulo Meira Reis. Rua Rodin 75, 07/402. Del Castilho, Rio de Janeiro, RJ, Brasil.

E-mail: romulomreis@hotmail.com; romulo.reis@facha. edu.br.

Manuscript received on February 2, 2021

Manuscript accepted on May 17, 2021

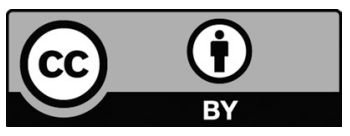

Motriz. The Journal of Physical Education. UNESP. Rio Claro, SP, Brazil - eISSN: 1980-6574 - under a license Creative Commons - Version 4.0 